\title{
PENILAIAN HASIL PEMBELAJARAN KEMAHIRAN BERBAHASA INDONESIA DENGAN PENDEKATAN KOMUNIKATIF
}

\author{
Sumadi \\ FBS Universitas Negeri Malang (www.sumadi.um.ac.id)
}

\begin{abstract}
Assessment of the Indonesian Language Learning Outcomes Using the Communicative Approach. Since the 1994 Curriculum was launched up to now, the assessment of the Indonesian language learning outcomes has been directed to the student's ability to use Indonesian communicatively in real situations. However, many teachers still assess such an ability based on the students' theoretical knowledge, not on their communicative ability. This might happen because of the teacher's lack of understanding about the use of the communicative approach in the Indonesian language learning. This article discusses the assessment of the Indonesian language learning outcomes using the communicative approach. The discussion consists of the assessment philosophy, techniques and procedures, rubrics, and sample test items constructed based on the communicative approach.
\end{abstract}

Keywords: assessment, communicative approach

\section{PENDAHULUAN}

Sejak diberlakukannya kurikulum pembelajaran bahasa Indonesia tahun 1994 dinyatakan secara eksplisit bahwa pembelajaran bahasa Indonesia dilakukan dengan menggunakan pendekatan komunikatif. Pada saat itu pembelajaran bahasa Indonesia menggunakan tiga pendekatan, yaitu (1) pendekatan komunikatif; (2) pendekatan tematik dan integratif; dan (3) pendekatan keterampilan proses dan CBSA (Cara Belajar Siswa Aktif). Pembelajaran bahasa Indonesia diarahkan pada kenyataan bahwa fungsi bahasa adalah sebagai alat komunikasi. Hal ini berarti bahwa pendekatan, metode, dan teknik pembelajaran bahasa Indonesia diarahkan untuk memahirkan siswa mahir berkomunikasi, bahan ajar diadopsi dari Kenyataan penggunaan bahasa Indonesia se- bagai alat komunikasi, dan untuk mengukur tingkat keberhasilan pembelajaran dilakukan dengan menggunakan pendekatan komunikatif. Proses komunikasi dapat terjadi jika ada tema sebagai pengikat yang melibatkan lebih dari satu domain kemahiran berbahasa, maka pembelajaran bahasa Indonesia digunakan pendekatan tematik dan integratif. Sementara itu, digunakannya pendekatan CBSA sebagai penegas bahwa tujuan pembelajaran adalah memahirkan siswa terampil berbahasa. Oleh karena itu, yang harus aktif berlatih berbahasa adalah siswa (Depdikbud, 1994).

Penggunaan pendekatan komunikatif dipertegas dengan diberlakukannya Kurikulum Berbasis Kompetensi tahun 2004. Dalam kurikulum ini dikemukakan bahwa bahasa memungkinkan ma- 
nusia untuk saling berkomunikasi, saling berbagi pengalaman, dan untuk meningkatkan kemampuan intelektual dan kesusastraan merupakan salah satu sarana untuk menuju pemahaman tersebut. Untuk itu dirumuskan standar kompetensi yang meliputi aspek kemahiran berbahasa dan kemahiran bersastra. Aspek kemahiran berbahasa meliputi kemahiran menyimak, berbicara, membaca, dan menulis, baik terkait dengan ragam bahasa nonsasra maupun ragam sastra. Siswa belajar bahasa sebagai alat komunikasi, bukan belajar teori bahasa. Oleh karena itu, rumusan kompetensi pada dasarnya juga hanya diarahkan pada pembentukan kemahiran menyimak, berbicara, membaca, dan menulis, baik dalam ragam sastra maupun nonsastra (Depdiknas, 2004).

Penggunaan pendekatan komunikatif dalam pembelajaran bahasa Indonesia dipertegas dalam KTSP (Kurikulum Tingkat Satuan Pendidikan). Sebagai penyempurnaan Kurikulum Berbasis Kompetensi (Muslich, 2008), tujuan pembelajaran dalam kurikulum ini adalah memahirkan siswa agar terampil berkomunikasi. Teknik dan prosedur penilaian untuk mengukur pencapaian keberhasilan pembelajaran bahasa Indonesia juga harus berorientasi pada penggunaan pendekatan komunikatif. Tetapi, kenyataannya sejauh ini masih banyak guru yang belum memahami penggunaan pendekatan komunikatif dalam pembelajaran bahasa Indonesia, termasuk penilaian kemahiran berbahasa dengan menggunakan pendekatan komunikatif. Berkaitan dengan itu, berikut dipaparkan penilaian hasil pembelajaran bahasa Indonesia dengan pende- katan komunikatif yang meliputi (1) filosofi penilaian kemahiran berbahasa Indonesia dengan menggunakan pendekatan komunikatif; (2) teknik dan prosedur penilaian kemahiran berbahasa Indonesia dengan pendekatan komunikatif; dan (3) contoh soal penilaian kemahiran berbahasa Indonesia dengan menggunakan pendekatan komunikatif.

\section{FILOSOFI PENILAIAN DENGAN PENDEKATAN KOMUNIKATIF}

Filosofi penilaian hasil pembelajaran kemahiran berbahasa Indonesia pendekatan komunikatif berangkat dari filosofi hakikat pembelajaran bahasa pendekatan komunikatif. Pendekatan ini berasumsi bahwa fungsi utama bahasa adalah sebagai alat komunikasi. Halliday dan Hasan (1985) menyatakan bahwa istilah "fungsi" bahasa dalam komunikasi secara sederhana dapat dipadankan dengan kata "penggunaan". Dengan demikian, apabila berbicara tentang fungsi bahasa dapat diartikan sebagai cara orang menggunakan bahasa mereka. Jika seseorang melakukan sesuatu dengan bahasa, orang itu berharap dapat mencapai banyak sasaran dan tujuan.

Hakikat bahasa adalah sebagai alat komunikasi dan tujuan pembelajaran bahasa adalah agar siswa mahir berkomunikasi, maka pembelajaran bahasa harus menggunakan pendekatan komunikatif. Artinya, perencanaan, pelaksanakan, dan penilaian pembelajaran harus didasarkan pada hakikat penggunaan bahasa sebagai alat komunikasi itu. Rumusan tujuan pembelajaran mengacu pada pembentukan kompetensi berbahasa yang secara garis besar dapat 
dipilah menjadi pembentukan empat kemahiran berbahasa. Materi pembelajaran mengacu pada model-model wacana yang digunakan sebagai sarana memahirkan siswa menggunakan bahasa. Metode dan teknik pembelajaran berupa model-model pembelajaran yang memungkinkan siswa berlatih menggunakan bahasa sebagaimana berkomunikasi senyatanya di masyarakat. Penilaian hasil pembelajaran bahasa juga harus sejalan dengan perencanaan dan pelaksanaan pembelajaran bahasa, yaitu menilai tingkat pencapaian kemahiran berbahasa siswa. Dengan kata lain, penilaian hasil pembelajaran bahasa juga harus sejalan dengan perencanaan dan pelaksanaan pembelajaran bahasa, yaitu menggunakan pendekatan komunikatif.

Dalam berbagai literatur, konsep kompetensi komunikatif itu diberi label istilah yang berbeda-beda dengan makna yang sama atau hampir sama. Carroll (1980) menggunakan istilah communicative 'performance' untuk bukunya dengan judul Testing Communicative Performance. Menurut Weir (1990), hal ini dapat dipahami apabila mengacu pada performansi individual dalam situasi tertentu. Tetapi, apabila mengacu pada berbagai situasi, komunikasi itu melibatkan competence dan performance yang oleh pengikut Widdowson (1983) disebut capacity (kapasitas). Bachman (1990) menggunakan istilah communicative language ability yang mengacu pada knowledge atau competence dan kapabilitas menerapkan kompetensi bahasa itu dalam language use. Widdowson (1978)memilahperformansi bahasa menjadi dua, yaitu language usage dan language use. Language usage adalah perfor- mansi bahasa lepas konteks, sedangkan language use adalah performansi bahasa untuk tujuan komunikasi yang sudah barang tentu berada dalam konteks.

Canale dan Swain (1980) menyatakan bahwa kompetensi komunikatif mencakup (1) kompetensi gramatikal (grammatical competence), yaitu pengetahuan seseorang tentang kaidah-kaidah gramatika bahasanya; (2) kompetensi sosiolinguistik (sociolinguistic competence), yaitu pengetahuan seseorang tentang kaidah-kaidah penggunaan dan kaidah-kaidah wacana dalam bahasanya; serta (3) kompetensi strategis (strategic competence), yaitu pengetahuan seseorang tentang strategi-strategi komunikasi verbal dan nonverbal dalam bahasanya. Allison (1999) menyatakan bahwa Canale (1983) mengubah model teoretis kompetensi komunikasi itu menjadi empat dimensi, yaitu kompetensi linguistik, kompetensi sosiolinguistik, kompetensi kewacanaan, serta kompetensi strategis. Kompetensi sosiolinguistik mengacu pada kompetensi kaidah-kaidah sosiokultural, sedangkan kompetensi kewacanaan mengacu pada kompetensi kaidah-kaidah kohesi dan koherensi.

Menurut Bachman (1990), communicative language ability terdiri atas kompetensi bahasa (language competence), kompetensi strategis (strategic competen$c e$ ), dan mekanisme psikofisiologis ( $p s y$ chophysiological mechanism). Kompetensi bahasa mencakup kompetensi organisasional bahasa yang terdiri atas kompetensi gramatikal dan tekstual, serta kompetensi pragmatik yang terdiri atas kompetensi illocutionary dan kompetensi sosiolinguistik. Kompetensi strategis 
berkenaan dengan hal-hal yang berkaitan dengan pencapaian tujuan komunikasi. Sementara itu, mekanisme psikofisiologis terjadi dalam pengimplementasian kompetensi. Kompetensi bahasa adalah gabungan antara pengetahuan dan keterampilan yang diperoleh untuk menerapkan sistem bahasa, untuk menepatkan makna ujaran, untuk mempekerjakan bahasa dalam konteks, dan untuk menerapkan bahasa pada level di atas kalimat. Kompetensi strategis mengacu pada pengetahuan dan keterampilan yang lebih umum berkaitan dengan pencapaian tujuan komunikasi yang efektif. Sementara itu, mekanisme psikofisiologis mengacu pada keterampilan dan faktor-faktor yang berkaitan dengan penggunaan bahasa dalam situasi yang sesungguhnya.

Hymes (1972) menyatakan bahwa kompetensi komunikatif mencakup kemampuan untuk menggunakan bahasa dan pengetahuan yang mendasari performansi bahasa. Sementara itu, istilah kapasitas (capacity) dan kemampuan (ability) untuk menggunakan bahasa secara komunikatif menurut Widdowson (1983) dan Bachman (1990) mengacu pada kompetensi (competence) dan keterampilan untuk menggunakan kompetensi itu dalam berbahasa yang sesungguhnya. Berkaitan dengan kompetensi komunikasi itu, Morrow (1979) dan Canale dan Swain (1980) menyatakan bahwa tes kemahiran berbahasa berkaitan dengan apa yang diketahui siswa tentang bentuk-bentuk bahasa yang mereka pelajari dan bagaimana peng-gunaannya dalam konteks yang sesungguhnya (competence), serta berkaitan dengan keterampilan siswa dalam meng- gunakan bahasa dalam situasi komunikasi yang bermakna (performance).

Djiwandodo(2008) menyatakan bahwa pendekatan komunikatif dapat dipahami sebagai pengembangan pendekatan pragmatik dengan cakupan yang jauh lebih luas, lebih beragam, dan lebih kompleks. Pendekatan komunikatif terhadap bahasa terkait juga dengan gagasan tentang konteks ekstralinguistik seperti halnya dalam pendekatan pragmatik, namun dengan cakupan yang lebih lengkap dan lebih luas karena bertitik tolak dari komunikasi sebagai fungsi utama dalam penggunaan bahasa. Dengan menitikberatkan pada fungsi utama sebagai alat komunikasi itu, pendekatan komunikatif pada penyelenggaraan pembelajaran bahasa dan tes bahasa tidak pertama-tama mengedepankan struktur bahasa dengan komponenkomponen dan unsur-unsurnya secara terpisah dan berkecil-kecil seperti pada penerapan pendekatan dikret. Pendekatan komunikatif tidak juga mendekati penggunaan bahasa sekadar sebagai penggabungan unsur-unsur bahasa itu secara integratif seperti pada pendekatan integratif. Pendekatan komunikatif bahkan juga tidak berangkat dari pemahaman tentang penggunaan bahasa dengan sekadar mempertimbangkan peran unsur-unsur ekstra linguistik seperti halnya pendekatan pragmatik.

\section{TEKNIK PENILAIAN DENGAN PEN- DEKATAN KOMUNIKATIF}

Sebagaimana dikemukakan sebelumnya bahwa kemahiran berbahasa meliputi empat subkemahiran, yaitu (1) kemahiran menyimak; (2) kemahiran berbicara; (3) kemahiran membaca; dan 
(4) kemahiran menulis. Teknik dan prosedur penilaian kemahiran berbahasa Indonesia terhadap empat subkemahiran tersebut disajikan berikut.

\section{Teknik dan Prosedur Penilaian Ke- mahiran Menyimak}

Dalam menjelaskan tes menyimak, Weir (1990) menggunakan istilah menyimak pemahaman. Istilah ini digunakan dengan meminjam istilah Vallete (1967) dengan alasan bahwa tujuan pokok tes menyimak adalah mengukur pemahaman siswa dalam menyimak. Selanjutnya, dia memilah tes menyimak itu menjadi dua, yaitu tes menyimak intensif dan tes menyimak ekstensif.

\section{Penilaian Kemahiran Menyimak Inten- sif}

Menyimak intensif adalah jenis menyimak dengan tujuan memahami informasi yang disampaikan secara tersurat dalam teks yang disimak. Dalam menyimak jenis ini,penyimak tidak perlu melakukan penafsiran dan penerkaan lebih jauh terhadap isi teks yang disimak. Penyimak tidak perlu membuat simpulan dengan melakukan analogianalogi terhadap teks lisan yang disimak dengan teks-teks lisan lain yang pernah disimak. Penyimak juga tidak perlu membuat simpulan dengan mendasarkan diri pada fakta-fakta, pengetahuan, atau pengalaman dirinya selain yang tersurat dalam teks lisan yang disimak. Weir (1990) mengemukakan ada dua jenis tes menyimak jenis ini, yaitu dictation dan listening recall.

Dikte adalah model penilaian kemahiran menyimak intensif yang paling mudah dilakukan. Dalam dikte, siswa harus memahami teks lisan yang disimaknya dan dalam waktu yang bersamaan siswa harus menuangkan kembali teks lisan yang disimak itu dalam bentuk tertulis. Teks tulis yang dihasilkan harus sama dengan teks lisan yang disimaknya. Besar kecilnya perbedaan antara teks lisan yang didengarnya dengan teks tulis yang dihasilkan menunjukkan kemahiran siswa tersebut dalam menyimak teks lisan yang disimaknya. Teknik dan prosedur penilaian kemahiran menyimak jenis ini adalah (1) menyuruh siswa untuk menyimak teks lisan dan pada saat yang bersamaan siswa ditugasi untuk menuliskan teks lisan yang disimak itu; (2) mengoreksi perbedaan teks tulis yang dihasilkan dengan teks lisan yang disimaknya; dan (3) menskor dan memberikan nilai pada teks tulis yang dihasilkan siswa berdasarkan kriteria tertentu.

Listening recall digunakan untuk mengukur ingatan siswa terhadap wacana lisan yang disimaknya. Dalam menilai kemampuan menyimak jenis ini digunakan teks tulis yang beberapa kata ke-n dalam teks tersebut dikosongkan seperti cloze test yang digunakan untuk mengukur kemahiran membaca pemahaman. Bedanya, teks yang digunakan dalam penilaian kemahiran menyimak ini adalah teks yang disimak siswa. Dalam teks itu, kata-kata yang dikosongkan dipilih kata-kata yang berjenis kata isi (content words) sehingga sama dengan selective deletion gap filling. Teknik dan prosedur penilaiannya adalah (1) memperdengarkan teks lisan kepada siswa; (2) memberikan "teks tulis" yang sama dengan teks lisan yang baru diperdengarkan kepada siswa, tetapi 
beberapa di antara kata yang ada dalam teks tersebut dikosongkan sehingga seperti cloze test dengan model selective deletion gap filling; lalu (3) siswa disuruh mengisi kata-kata yang dikosongkan itu. Jumlah isian benar yang dilakukan siswa merupakan gambaran kemampuan menyimak ingatan (listening recall) siswa tersebut.

\section{Penilaian Kemahiran Menyimak Eks- tensif}

Menyimak ekstensif ialah upaya memahami isi teks lisan yang disimak secara komprehensif, tidak hanya isi teks lisan yang disampaikan secara tersurat, tetapi juga yang disampaikan secara tersirat dan tersorot. Oleh karena itu, penilaian kemahiran menyimak ekstensif tidak hanya mengukur kemampuan siswa dalam memahami isi teks lisan secara tersurat, tetapi juga yang disampaikan secara tersurat dan tersorot. Menurut Weir (1990), ada tiga teknik yang dapat digunakan untuk mengukur kemahiran menyimak jenis ini, yaitu (1) teknik tes bentuk pilihan ganda (multiple-choice questions); (2) teknik tes bentuk jawaban singkat (short answer questions); dan (3) teknik transfer informasi (information transfer techniques).

Penilaian kemahiran menyimak ekstensif dengan bentuk pilihan ganda dilakukan dengan menggunakan teks lisan yang disertai dengan sejumlah pertanyaan yang disusun dalam bentuk pilihan ganda. Penyusunan pilihan jawaban, baik jawaban benar maupun pengecohnya, tidak hanya didasarkan pada informasi yang dinyatakan secara tersurat dalam teks, tetapi juga didasar- kan pada informasi yang dinyatakan secara tersurat dan tersorot. Prosedur penilaiannya adalah (1) memperdengarkan teks lisan kepada siswa dan siswa ditugasi untuk menyimaknya; (2) memberikan sejumlah soal pilihan ganda (dapat dilakukan secara lisan dan dapat pula dilakukan secara tertulis); lalu (3) mengoreksi dan menilai jawaban siswa. Jumlah jawaban benar yang dimiliki siswa merupakan gambaran kemahiran menyimak ekstensif siswa yang bersangkutan.

Penilaian kemahiran menyimak ekstensif dengan teknik transfer informasi dilakukan dengan menugasi siswa untuk mentransfer isi teks lisan yang baru disimaknya dalam bentuk lain dengan bahasa mereka sendiri. Transfer informasi itu dapat dilakukan secara lisan dalam bentuk berbicara dan dapat pula dilakukan secara tertulis dalam bentuk mengarang. Karena penilaian ini dimaksudkan untuk menilai kemahiran menyimak, fokus penilaiannya harus mengacu pada kemahiran menyimak ekstensif, yaitu menangkap informasi yang disampaikan secara lisan kepada penyimak. Teknik dan prosedur penilaiannya adalah (1) memperdengarkan teks lisan kepada siswa dan siswa ditugasi untuk menyimaknya; (2) menyuruh siswa untuk menuangkan kembali isi teks lisan yang baru disimaknya secara lisan dalam bentuk berbicara atau dalam bentuk tertulis dalam bentuk mengarang; lalu (3) mengoreksi dan menilai wicara atau karangan siswa. Kebenaran informasi yang diungkapkan kembali oleh siswa, misalnya kelengkapan, kepaduan, keruntutan, dan lain-lain merupa- 
kan gambaran kemahiran menyimak ekstensif siswa yang bersangkutan.

\section{Teknik dan Prosedur Penilaian Kema- hiran Berbicara}

Berbicara pada hakikatnya adalah kemahiran berkomunikasi lisan yang bersifat aktif produktif dan spontan. Oleh karena itu, teknik dan prosedur penilaian kemahiran berbicara harus mengacu pada hakikat kemahiran berbicara tersebut. Weir (1990) menyatakan ada delapan teknik yang dapat digunakan untuk mengukur dan menilai kemahiran berbicara ini, yaitu verbal essay, oral presentation, the free interview, the control interview, information transfer: description of a picture sequence, information transfer: questions on a single picture, interaction tasks, dan role play.

Penilaian kemahiran berbicara dengan verbal essay dilakukan dengan menyuruh siswa untuk berbicara tentang topik umum dalam rentang waktu kirakira tiga menit. Teknik dan prosedur penilaiannya adalah (1) menunjuk siswa tertentu untuk berbicara tentang topik umum dalam rentang waktu kirakira tiga menit; dan (2) siswa yang lain dan atau guru mengadakan penilaian dengan berpedoman pada rubrik penilaian kemahiran berbicara.

Penilaian kemahiran berbicara dengan oral presentation hampir sama dengan verbal essay. Bedanya adalah siswa ditugasi untuk berbicara tentang topik tertentu yang sudah dipersiapkan sebelumnya. Penilaian kemahiran berbicara dapat dilakukan dengan memberikan tugas kepada siswa untuk mengadakan wawancara bebas. Teknik dan prosedur penilaiannya adalah (1) menyuruh sis- wa untuk mengadakan wawancara kepada orang lain, bisa kepada sesama teman; dan (2) siswa yang lain dan atau guru mengadakan penilaian. Karena penilaian ini bertujuan untuk menilai kemahiran berbicara pewawancara, bukan kemahiran berbicara orang yang diwawancarai, fokus penilaiannya diarahkan pada kemahiran berbahasa pewawancara.

Penilaian kemahiran berbicara dengan menggunakan wawancara terstruktur ini hampir sama dengan penilaiankemahiranberbicara dengan menggunakan wawancara bebas. Bedanya terletak pada digunakannya pedoman wawancara bagi pewawancara. Oleh karena itu, prosedur penilaiannya adalah (1) menyuruh siswa untuk mengadakan wawancara kepada orang lain, bisa kepada sesama teman; (2) siswa yang lain dan atau guru mengadakan penilaian. Di sini, fokus penilaian juga diarahkan pada kemahiran berbahasa pewawancara, bukan tingkat kemahiran berbicara orang yang diwawancarai.

Dalam penilaian kemahiran berbicara dengan menggunakan teknik information transfer: description of a picture sequence ini dilakukan dengan menggunakan gambar berangkai yang menggambarkan urutan peristiwa atau kejadian. Gambar berangkai ini digunakan sebagai pancingan agar siswa berbahasa secara lisan dalam bentuk berbicara. Teknik dan prosedur penilaiannya adalah (1) menyuruh siswa untuk mengamati gambar berangkai yang sudah disediakan guru; (2) menyuruh siswa untuk menceritakan isi gambar berangkai menurut penafsiran siswa; dan (3) siswa lain dan atau guru mengadakan penilai- 
an dengan menggunakan rubrik penilaian.

Penilaian kemahiran berbicara dengan information transfer: questions on a single picture digunakan untuk mengukur dan menilai kemahiran berbicara siswa yang kemahiran berbicaranya sudah cukup tinggi. Dalam teknik ini, gambar yang digunakan berupa gambar tunggal. Prosedur penilaiannya adalah (1) menyuruh siswa untuk mengamati gambar tunggal yang sudah disediakan; (2) mengajukan sejumlah pertanyaan kepada siswa berkaitan dengan isi gambar itu; (3) menyuruh siswa untuk menceritakan isi gambar itu dengan berpedoman pada sejumlah pertanyaan yang disediakan pada langkah 2; serta (3) siswa lain dan atau guru mengadakan penilaian dengan menggunakan rubrik penilaian kemahiran berbicara.

Penilaian kemahiran berbicara dengan tugas berinteraksi digunakan untuk menilai kemahiran berbicara siswa tingkat menengah, yaitu siswa yang sudah mempunyai keberanian cukup untuk berinteraksi. Dengan berpasangan, siswa ditugasi untuk saling mengisi informasi yang diperlukan pasangannya. Prosedur penilaiannya adalah (1) menyuruh siswa untuk berpasangan; (2) menyuruh pasangan itu untuk berkomunikasi dan saling melengkapi demi terjadinya proses komunikasi; serta (3) siswa lain dan atau guru mengadakan penilaian dengan menggunakan rubrik penilaian kemahiran berbicara.
Bermain peran (role play) digunakan untuk menilai tingkat kemahiran berbicara siswa yang tingkat kemahiran berbicaranya sudah cukup baik. Secara berkelompok, siswa ditugasi untuk bermain peran, berinteraksi dengan menggunakan bahasa seperti yang terjadi sesungguhnya dalam masyarakat. Prosedur penilaiannya adalah (1) menugasi siswa untuk membentuk kelompok; (2) menugasi siswa untuk memilih peristiwa komunikasi yang ada dalam masyarakat yang akan diperankan; (3) menugasi siswa untuk berbagi peran yang diperlukan dalam peristiwa komunikasi itu; dan (4) menugasi siswa untuk bermain peran sesuai dengan yang direncanakan.

Sebenarnya masih ada teknik yang dapat digunakan untuk menilai kemahiran berbicara, yaitu dengan memberi tugas berpidato. Teknik ini dalam pelaksanaannya memerlukan waktu yang cukup banyak sehingga kurang sesuai untuk menilai kemahiran berbicara sejumlah siswa sekaligus. Prosedur penilaiannya adalah (1) menugasi siswa untuk membuat persiapan pidato; (2) menugasi siswa untuk berpidato sesuai dengan persiapan yang sudah dibuat; dan (3) siswa yang lain dan atau guru mengadakan penilaian dengan menggunakan rubrik penilaian kemahiran berbicara.

Berikut disajikan contoh rubrik penilaian kemahiran berbicara. Rubrik ini dapat digunakan untuk menilai berbagai kemahiran berbicara sebagaimana dikemukakan di atas. 
Tabel 1: Rubrik Penilaian Kemahiran Berbicara

\begin{tabular}{|c|c|c|c|c|}
\hline No. & Aspek & Subaspek & Kriteria & Skor \\
\hline \multirow[t]{20}{*}{1.} & Bahasa & a. Ketepatan pelafalan & a. Sangat tepat & 4 \\
\hline & & & b. Tepat & 3 \\
\hline & & & c. Kurang tepat & 2 \\
\hline & & & d. Tidak tepat & 1 \\
\hline & & b. Kejelasan pelafalan & a. Sangat jelas & 4 \\
\hline & & & b. Jelas & 3 \\
\hline & & & c. Kurang jelas & 2 \\
\hline & & & d. Tidak jelas & 1 \\
\hline & & c. Pilihan kata & a. Sangat tepat & 4 \\
\hline & & & b. Tepat & 3 \\
\hline & & & c. Kurang tepat & 2 \\
\hline & & & d. Tidak tepat & 1 \\
\hline & & d. Struktur kalimat & a. Sangat tepat & 4 \\
\hline & & & b. Tepat & 3 \\
\hline & & & c. Kurang tepat & 2 \\
\hline & & & d. Tidak tepat & 1 \\
\hline & & e. Paraton & a. Sangat tepat & 4 \\
\hline & & & b. Tepat & 3 \\
\hline & & & c. Kurang tepat & 2 \\
\hline & & & d. Tidak tepat & 1 \\
\hline \multirow[t]{12}{*}{2.} & Isi & a. Kelengkapan & a. Sangat lengkap & 4 \\
\hline & & & b. Lengkap & 3 \\
\hline & & & c. Kurang lengkap & 2 \\
\hline & & & d. Tidak lengkap & 1 \\
\hline & & b. Keruntutan & a. Sangat runtut & 4 \\
\hline & & & b. Runtut & 3 \\
\hline & & & c. Kurang runtut & 2 \\
\hline & & & d. Tidak runtut & 1 \\
\hline & & c. Kepaduan & a. Sangat padu & 4 \\
\hline & & & b. Padu & 3 \\
\hline & & & c. Kurang padu & 2 \\
\hline & & & d. Tidak padu & 1 \\
\hline \multirow[t]{8}{*}{3.} & Fisik & a. Mimik & a. Sangat tepat & 4 \\
\hline & & & b. Tepat & 3 \\
\hline & & & c. Kurang tepat & 2 \\
\hline & & & d. Tidak tepat & 1 \\
\hline & & b. Gesture & a. Sangat tepat & 4 \\
\hline & & & b. Tepat & 3 \\
\hline & & & c. Kurang tepat & 2 \\
\hline & & & d. Tidak tepat & 1 \\
\hline \multirow[t]{4}{*}{4.} & Kelancaran & & a. Sangat lancar & 4 \\
\hline & & & b. Lancar & 3 \\
\hline & & & c. Kurang lancar & 2 \\
\hline & & & d. Tidak lancar & 1 \\
\hline
\end{tabular}

Jumlah skor yang diperoleh siswa

Nilai $=$ $x 100$

Jumlah skor maksimal 
Teknik dan Prosedur Penilaian Kemahiran Membaca

Kemahiran membaca dapat dipilah menjadi membaca indah, membaca pemahaman, dan membaca cepat. Dalam artikel ini dipaparkan penilaian kemahiran membaca teknik dan kemahiran membaca pemahaman. Membaca teknik dikenal juga dengan istilah membaca indah. Pembaca dikategorikan mahir apabila dapat membaca bersuara dengan pelafalan, jeda, nada, dan intonasi yang tepat. Agar dapat membaca indah dengan benar sudah barang tentu pem- baca harus dapat memahami isi teks yang dibacanya. Contoh membaca jenis ini dapat dilihat pada saat pembaca berita di station TV tertentu membacakan berita.

Penilaian kemahiran membaca jenis ini mudah. Teknik dan prosedur penilaian membaca jenis ini adalah (1) menyesediakan teks yang sesuai dengan tingkat siswa; (2) menyuruh siswa tertentu untuk membaca teks bacaan yang telah disediakan; dan (3) siswa lain dan atau guru mengadakan penilaian dengan rubrik penilaian berikut.

Tabel 2: Rubrik Penilaian Kemahiran Membaca Indah

\begin{tabular}{|c|c|c|c|}
\hline No. & Aspek & Kriteria & Skor \\
\hline \multirow[t]{4}{*}{1.} & Ketepatan pelafalan & a. Sangat tepat & 4 \\
\hline & & b. Tepat & 3 \\
\hline & & c. Kurang tepat & 2 \\
\hline & & d. Tidak tepat & 1 \\
\hline \multirow[t]{4}{*}{2.} & Kejelasan pelafalan & a. Sangat jelas & 4 \\
\hline & & b. Jelas & 3 \\
\hline & & c. Kurang jelas & 2 \\
\hline & & d. Tidak jelas & 1 \\
\hline \multirow[t]{4}{*}{3.} & Jeda & a. Sangat tepat & 4 \\
\hline & & b. Tepat & 3 \\
\hline & & c. Kurang tepat & 2 \\
\hline & & d. Tidak tepat & 1 \\
\hline \multirow[t]{4}{*}{4.} & Nada & a. Sangat tepat & 4 \\
\hline & & b. Tepat & 3 \\
\hline & & c. Kurang tepat & 2 \\
\hline & & d. Tidak tepat & 1 \\
\hline \multirow[t]{4}{*}{5.} & Intonasi & a. Sangat tepat & 4 \\
\hline & & b. Tepat & 3 \\
\hline & & c. Kurang tepat & 2 \\
\hline & & d. Tidak tepat & 1 \\
\hline \multirow[t]{4}{*}{6.} & Kelancaran & a. Sangat lancar & 4 \\
\hline & & b. Lancar & 3 \\
\hline & & c. Kurang lancar & 2 \\
\hline & & d. Tidak lancar & 1 \\
\hline
\end{tabular}

Jumlah skor yang diperoleh siswa

Nilai =-------------------------- x 100

Jumlah skor maksimal 
Berkaitan dengan penilaian kemahiran membaca pemahaman, Weir (1990) menyatakan ada tujuh teknik yang dapat digunakan dalam penilaian kemahiran membaca pemahaman. Ketujuh teknik itu adalah (1) dengan tes pilihan ganda (multiple-choice questions); (2) dengan tes jawaban singkat (short answer questions); (3) dengan cloze test; (4) dengan selective deletion gap filling; (5) dengan C-test; (6) dengan cloze elide; dan (7) dengan transfer informasi (information transfer).

Teknik dan prosedur penilaian kemahiran membaca pemahaman dengan tes pilihan ganda dan jawaban singkat pada dasarnya hampir sama. Yang membedakan adalah bentuk soal yang disertakan pada teks bacaan yang digunakan sebagai bahan penilaian, yaitu dapat digunakan soal berbentuk pilihan ganda dan dapat digunakan soal berbentuk isian singkat. Teknik dan prosedur penilaiannya dapat dipilah menjadi dua tahap, yaitu tahap persiapan dan tahap pelaksanaan. Pada tahap persiapan, teknik dan dan prosedurnya meliputi (1) menyediakan teks bacaan yang sesuai dengan kemampuan siswa; (2) melengkapi teks bacaan tersebut dengan sejumlah soal pilihan ganda atau isian singkat; (3) kalau diperlukan mengujicobakan soal; dan (4) menggandakan soal. Pada saat penilaian, teknik dan prosedurnya meliputi (1) menyuruh siswa untuk membaca dan menjawab sejumlah pertanyaan yang telah disediakan; (2) mengoreksi lembar jawaban siswa; dan (3) mengadakan penilaian.
Teknik dan prosedur penilaian dengan dengan cloze test, dengan selective deletion gap filling, dengan C-test, dan dengan cloze elide juga hampir sama. Pada tahap persiapan, guru memilih teks yang sesuai dengan tingkat kemahiran siswa. Dari teks tersebut dikosongkan setiap kata ke-n untuk cloze test, setiap kata jenis tertentu ke-n untuk selective gap filling, paroh kata ke-n untuk C-tes, dan menyisipkan pilihan kata tertentu pada kata ke-n untuk cloze elide. Selanjutnya, soal tersebut diujicobakan dan digandakan. Pada tahap pelaksanaan, teknik dan prosedur pelaksanaannya adalah (1) menugasi siswa untuk membaca teks; (2) menugasi siswa untuk mengisi bagian teks yang rumpang atau memilih isian yang tepat; (3) mengoreksi jawaban siswa; dan (4) mengadakan penilaian. Jumlah jawaban yang benar mencerminkan tingkat pemahaman siswa terhadap teks tersebut.

Teknik dan prosedur penilaian kemahiran membaca pemahaman dengan transfer informasi juga dilakukan pada dua tahapan. Pada saat persiapan, guru memilih teks yang sesuai dengan tingkat kemahiran siswa. Pada tahap pelaksanaan, teknik dan prosedur pelaksanaannya adalah (1) menugasi siswa untuk membaca teks yang telah disediakan; (2) menugasi siswa untuk mengungkapkan kembali isi teks yang baru dibacanya ke dalam bentuk tulis (mengarang) atau dalam bentuk lisan (berbicara); (3) mengoreksi jawaban siswa; dan (4) mengadakan penilaian. Karena yang menjadi fokus penilaian di sini adalah tingkat pemahaman siswa terhadap teks yang dibacanya, maka yang 
dinilai adalah kesesuaian isi karangan siswa (bukan penggunaan ejaan, tanda baca, dan lain-lain) atau kesesuaian isi bicara siswa (bukan pelafalan, jeda, dan lain-lain) dengan teks yang baru dibacanya.

\section{Teknik dan Prosedur Penilaian Kema- hiran Menulis}

Kemahiran menulis adalah kemahiran menuangkan atau menyampaikan ide, gagasan, perasaan kepada orang lain dengan menggunakan bahasa tulis. Kemahiran menulis adalah kemahiran berbahasa yang bersifat aktif produktif tulis. Berbeda dengan kemahiran berbahasa yang bersifat aktif produktif lisan, dalam kemahiran menulis tersedia waktu yang cukup untuk memperbaiki kesalahan berbahasa dengan cara mengoreksi kesalahan yang ada dalam teks tulis yang baru dibuatnya. Berkaitan dengan ini, Weir (1990) menyatakan bahwa penilaian kemahiran menulis dapat dilakukan dengan dua cara, yaitu (1) dengan tugas menulis tidak langsung; dan (2) dengan tugas menulis langsung.

Teknik penilaian kemahiran menulis dengan tugas menulis tidak langsung dilakukan dengan tugas mengedit teks bacaan yang beberapa bagiannya disengaja salah. Kesalahan yang dimaksud dapat berupa kesalahan penggunaan ejaan, kesalahan penggunaan tanda baca, kesalahan pilihan kata, kesalahan struktur frasa, kesalahan struktur kalimat, dan sebagainya. Disebut tugas menulis tidak langsung karena teks bacaan itu sudah disediakan oleh penyusun soal, bukan oleh siswa. Tugas siswa adalah mengedit teks tersebut dengan membetulkan bagian-bagian teks yang salah sehingga teks tersebut menjadi sebuah teks yang benar.

Penilaian kemahiran menulis yang dilakukan dengan teknik menulis langsung dilakukan dengan tugas menulis bebas (essay test) dan menulis terbimbing (controlled writing taks). Teknik ini disebut teknik menulis langsung karena teks yang dihasilkan benar-benar ditulis langsung oleh siswa. Siswalah yang membuat judul, mengembangkan paragraf, menyusun kalimat, memilih kata, menggunakan ejaan, dan menggunakan tanda baca. Dalam tugas menulis bebas, siswa diberi keleluasaan untuk memilih topik, judul karangan, panjang karangan, dan sebagainya, sedangkan dalam tugas menulis terbimbing siswa dibatasi pada, misalnya, topik tertentu, jumlah paragraf, panjang karangan, dan sebagainya.

Dalam menilai karangan siswa dapat dilakukan dengan dua pendekatan, yaitu analitik dan holistik. Penilaian secara analitik dilakukan dengan memberi tanda pada setiap aspek kemahiran mengarang, mengelompokkannya, dan selanjutnya memberi skor dan nilai berdasarkan aspek-aspek yang membangun kemahiran mengarang itu, sedangkan penilaian secara holistik dilakukan dengan membaca secara utuh karangan itu dan secara impresif penilai dapat memberikan keputusan berapa skor dan nilai karangan itu. Apabila penilaian dilakukan secara analitik, dapat digunakan rubrik penilaian kemahiran menulis berikut. 
Tabel 3. Rubrik Penilaian Kemahiran Menulis

\begin{tabular}{|c|c|c|c|c|}
\hline No. & Aspek & Subaspek & Kriteria & Skor \\
\hline \multirow[t]{24}{*}{1.} & Bahasa & a. Rumusan judul & a. Sangat tepat & 4 \\
\hline & & & b. Tepat & 3 \\
\hline & & & c. Kurang tepat & 2 \\
\hline & & & d. Tidak tepat & 1 \\
\hline & & b. Penggunaan ejaan & a. Sangat tepat & 4 \\
\hline & & & b. Tepat & 3 \\
\hline & & & c. Kurang tepat & 2 \\
\hline & & & d. Tidak tepat & 1 \\
\hline & & c. Penggunaan tanda baca & a. Sangat tepat & 4 \\
\hline & & & b. Tepat & 3 \\
\hline & & & c. Kurang tepat & 2 \\
\hline & & & d. Tidak tepat & 1 \\
\hline & & d. Pilihan kata & a. Sangat tepat & 4 \\
\hline & & & b. Tepat & 3 \\
\hline & & & c. Kurang tepat & 2 \\
\hline & & & d. Tidak tepat & 1 \\
\hline & & e. Struktur kalimat & a. Sangat tepat & 4 \\
\hline & & & b. Tepat & 3 \\
\hline & & & c. Kurang tepat & 2 \\
\hline & & & d. Tidak tepat & 1 \\
\hline & & f. Paragraf & a. Sangat tepat & 4 \\
\hline & & & b. Tepat & 3 \\
\hline & & & c. Kurang tepat & 2 \\
\hline & & & d. Tidak tepat & 1 \\
\hline \multirow[t]{12}{*}{2.} & Isi & a. Kelengkapan & a. Sangat lengkap & 4 \\
\hline & & & b. Lengkap & 3 \\
\hline & & & c. Kurang lengkap & 2 \\
\hline & & & d. Tidak lengkap & 1 \\
\hline & & b. Keruntutan & a. Sangat runtut & 4 \\
\hline & & & b. Runtut & 3 \\
\hline & & & c. Kurang runtut & 2 \\
\hline & & & d. Tidak runtut & 1 \\
\hline & & c. Kepaduan & a. Sangat padu & 4 \\
\hline & & & b. Padu & 3 \\
\hline & & & c. Kurang padu & 2 \\
\hline & & & d. Tidak padu & 1 \\
\hline
\end{tabular}

Jumlah skor yang diperoleh siswa

Nilai = ------------------------- x 100

Contoh Soal Menulis dengan Pendekatan Komunikatif

Sebagaimana dikemukakan dalam uraian filosofi penilaian hasil pembelajaran kemahiran berbahasa Indonesia dengan menggunakan pendekatan ko- munikatif,penilaian kemahiran berbahasa itu tidak sama sekali meninggalkan penilaian terhadap kompetensi bahasa siswa. Menurut Canale dan Swain (1980), kompetensi bahasa itu mencakup juga kompetensi gramatikal, yaitu 
pengetahuan tentang kaidah tata bahasa. Selanjutnya, Canale mengembangkan teorinya tentang kompetensi komunikatif yang mencakup pula kompetensi linguistik (Allison, 1999). Persoalannya adalah bagaimana butir soal yang mengukur kemampuan bahasa, tetapi dirancang tetap menggunakan pendekatan komunikatif. Berikut disajikan contoh yang digunakan untuk mengukur pengetahuan tentang bahasa Indonesia dengan pendekatan komunikatif.

\section{Soal Kemampuan Memahami Imbuhan}

Orang itu mendapatkan penghargaan sebagai novelis terbaik. Kalimat berikut yang sama maknanya dengan kalimat ini adalah ...

A. Orang itu mendapatkan penghargaan sebagai penjual novel terbaik.

B. Orang itu mendapatkan penghargaan sebagai penyimpan novel terbaik.

C. Orang itu mendapatkan penghargaan sebagai penulis novel terbaik.

D.Orang itu mendapatkan penghargaan sebagai perawat novel terbaik.

Jawaban: C

Soal ini tidak mengukur penguasaan teori tentang bahasa, tetapi mengukur kemampuan siswa dalam berbahasa. Bandingkan dengan soal berikut!

Orang itu mendapatkan penghargaan sebagai novelis terbaik. Arti imbuhan -is dalam kata novelis adalah ....
A.penjual
B. penyimpan
C. penulis
D. perawat
Jawaban: C

Soal ini mengukur penguasaan siswa tentang teori bahasa, yaitu penguasaan siswa tentang arti imbuhan -is, bu- kan kemampuan siswa dalam berbahasa. Soal ini disusun tidak menggunakan pendekatan komunikatif.

\section{Soal Kemampuan Menulis}

(1) Festival bertajuk Banteng Nuswantara itu cukup menyedot puluhan ribu penonton.

(2) Salah satunya dengan menggelar pertunjukkan kesenian tradisional bantengan.

(3) Mereka sangat penasaran ingin melihat penampilan 110 bantengan itu.

(4) Beragam program dilakukan di kota Batu untuk menunjang promosi pariwisata.

Keempat kalimat tersebut dapat disusun menjadi paragraf yang baik dengan urutan ....

A. (1), (3), (2), (4)

B. (3), (1), (2), (4)

C. (4), (3), (1), (2)

D. (4), (2), (1), (3)

Jawaban: D

\section{PENUTUP}

Penilaian hasil pembelajaran kemahiran berbahasa Indonesia sudah seharusnya dilakukan dengan menggunakan pendekatan komunikatif. Hal ini sejalan dengan penggunaan pendekatan komunikatif dalam pembelajaran bahasa Indonesia. Agar pembelajaran bahasa Indonesia berhasil dengan baik, guru harus mampu membuat rencana perencanaan pembelajaran (RPP), melaksanakan pembelajaran sesuai dengan RPP itu, serta mampu mengevaluasi hasil pembelajaran kemahiran berbahasa Indonesia secara konsisten dengan pendekatan yang sama, yaitu pendekatan komunikatif. 
Uraian pendahuluan, filosofi, berbagai teknik dan prosedur penilaian, contoh rubrik, serta contoh soal dalam artikel ini disusun agar dapat digunakan oleh pemerhati dan atau guru bahasa Indonesia sebagai rujukan dalam kajian teoretis maupun kepentingan praktis pembelajaran bahasa Indonesia. Uraian tersebut tidak diacukan secara khusus pada tingkat satuan pendidikan (SD, SMP, SMA, atau SMK) dengan harapan kita semua berpikir tentang teknik dan prosedur mana yang paling cocok untuk setiap satuan tingkat pendidikan itu.

\section{UCAPAN TERIMA KASIH}

Terima kasih saya ucapkan kepada Dewan Redaksi Jurnal Cakrawala Pendidikan yang telah memberi saran yang berharga bagi perbaikan artikel ini. Terima kasih juga saya ucapkan kepada staf Jurnal Cakrawala Pendidikan Universitas Negeri Yogyakarta.

\section{DAFTAR PUSTAKA}

Allison, Desmond. 1999. Language Testing $\mathcal{E}$ Evaluation: An Introductory Course. Singapore: Singapore University Press.

Bachman, L.F. 1990. Fundamental Considerations in Testing. Oxford: Oxford University Press.

Canale, M. dan Swain, M. 1980. “Theoretical Basis of Communicative Approaches to Second Language Teaching and Testing". Aplied Linguistics, I: 1-47.
Canale, M. 1983. “On some Dimensions of Language Proficiency". in Oller, J.W. (ed.). 1983: Issues in Language Testing Research: 333342. Rowley, M.A: Newbury House.

Carroll, B.J. 1980. Testing Communicative Performance. Oxford: Pergamon.

Departemen Pendidikan dan Kebudayaan. 1994. Kurikulum 1994 Mata Pelajaran Bahasa Indonesia. Jakarta: Pusat Kurikulum Depdikbud.

Departemen Pendidikan Nasional. 2004. Kurikulum 2004: Standar Kompetensi. Jakarta: Pusat Kurikulum, Balibang Depdiknas.

Djiwandono, M. Soenardi. 2008.Tes Bahasa: Pegangan bagi Pengajar Bahasa. Jakarta: PT Indeks.

Hymes, D.H. 1972. “On Communicative Competence". in Pride, J.B. and Holmes, J. (eds.). Sociolinguistics: Selected Reading: 269-93.

Muslich, Masnur. 2008. KTSP: Pembelajaran Berbasis Kompetensi dan Kontekstual. Jakarta: PT Bumi Aksara.

Morrow,K.E.1979. Communicative Language Testing: Revolution or Evolution. in Brumfit, M. (ed.), 1986:113.

Valette, R.M. 1967. Modern Language Testing. New York: Harcourt, Brace, and World. 
Weir, Cyril J. 1990. Communicative Language Testing. New York: Prentice Hall.

Widdowson, H.G. 1978. Teaching Language as Communication. Oxford: Oxford University Press.

. 1983. Learning Purpose and Language Use. Oxford: Oxford University Press. 